\title{
Education and the labor \\ market in Latin America: confronting globalization
}

\section{Beverley Carlson}

Division of Production,

Productivity and Management,

ECLAC

bcarlson@eclac.cl
This article analyses the challenges facing education in Latin

America and its relation to labor market performance, against

a background of severe long-standing income and social inequalities and now also the effects of globalization. It examines the degree to which higher educational attainment results in positive labor market outcomes (employment and earnings) and finds that, in spite of very large investments in education reform, the Latin American countries are falling behind their global competitors. Calculations made by the author of the education premiums in selected countries, by educational attainment and gender, show that labor market returns to education are positive or mixed but, in the case of unemployment, are often negative. The article suggests policies that could provide a more competitive labor force and more prepared human capital, and concludes with concrete proposals for confronting globalization. 


\title{
I
}

\section{Introduction}

\author{
"Beginning in the mid-1970s, a new set of priorities began to influence \\ education policy discourse around the world. The new priorities valued \\ the development of individual, national and global competitiveness... \\ In education, this translated into a greater priority accorded to quality.... \\ As a result of the new education priorities, policy makers have initiated \\ reforms during the past twenty years that aim to achieve a better link \\ between the products of the education system and the needs of the economy..."
}

(REIMERS, ed., 2000).

Education in Latin America has four major problem areas. The level of educational attainment has increased more slowly than in other regions in recent decades as a result of deficiencies in the scope of secondary education, with children leaving the school system early, especially before completion of their secondary education. The disparity in educational attainment is high because, although younger generations receive more education than older ones, within each generation there are major income, social class and location differences in educational achievement. The returns to education are low for the first years of school and non-university post-secondary education, but high for university education. They are also substantially lower in rural than in urban areas. Educational quality is much lower for students from low-income families, most of whom attend public schools and do not have access to better quality higher education. In short, education is profoundly stratified in Latin America: an effect that is perpetuating, rather than correcting, income inequalities.

The increase in recent decades in the average number of years of schooling of youth, as compared to their parents, has not sufficiently improved the opportunities of young people from poor social strata, who earn $30 \%$ to $40 \%$ less than youths with the same level of education but coming from households where parents have higher incomes (ECLAC, 1998). Countries, and particularly those with economies that need to become more knowledge-based, cannot afford in the

This article is based on a text prepared as a support paper for the ECLAC document entitled Globalization and development (LC/ G.2157 (SES.29/3)) presented at the $29^{\text {th }}$ session of the Commission, held at Brasilia from 6-10 May 2002. long run to exclude a large part of their population from access to quality education and learning resources. Furthermore, inequalities in societies raise problems of mutual mistrust in the workplace and in society as a whole. At the heart of the political debate is a growing awareness that the global changes promising to enhance prosperity also risk increasing inequalities and dividing societies (CERI (Centre for Educational Research and Innovation), 2001a). More and better higher education is a necessary but not sufficient condition for faster and more equitable growth. Macro stability and meso and micro remedial policy actions, together with institutionbuilding efforts, are also needed if Latin American countries are to attain a better and socially more equitable long-term performance.

This article examines two pivotal education and labor market policy and performance questions. One, the degree to which countries in the Latin American region are catching up or falling behind their global competitors, in both developing and industrial regions, in the formation of human capital, with particular reference to upper secondary and technical education. Two, the degree to which higher educational attainment in Latin American countries results in positive labor market outcomes ${ }^{1}$ including labor force participation, employment, unemployment, and earnings. It finds that, in spite of very large investments in education reform, Latin American countries are falling behind their global

\footnotetext{
${ }^{1}$ It should be noted that the expression "labour market outcomes of education" is the standard and internationally accepted OECD terminology. It implies of course a causal relationship, which we can agree exists, but this in no sense means that the "labour market outcomes" discussed here are due only to education. As noted in the paper, performance in the labour market is subject to many factors, of which education is one of the most important.
} 
competitors in these key educational areas and that the pattern of positive labor market returns to education, which is fairly consistent throughout the OECD countries, is much more mixed in the Latin American countries and in a number of cases is even negative. In order to examine these questions, the author calculates education premiums for selected Latin American countries, using data from two rounds of national household surveys, the first between 1993 and 1996 and the second in 1999 (Carlson, 2001). Finally, policy proposals regarding these questions and the means for achieving them are made.

The effects of globalization further complicate the already complex and fragile relationship between the supply and demand for labor within countries. Domestic labor markets are being increasingly buffeted by the growing influence of multinational enterprises. The impact of their highly centralized corporate decisions is felt simultaneously in many countries, especially in the case of job cuts. The massive job losses throughout 2001 in Latin American countries are living proof of the increasing exposure of domestic labor markets to international shocks and globalized decisions (Carlson, 2002). The point that this article makes is that obtaining more and better education is one of the most important actions that workers can take to prepare themselves to confront globalization. While this is not in itself sufficient, it is becoming more and more necessary.

Confronting globalization means realizing where job creation has taken place. As a result of a series of factors identified by Reinhardt and Peres (2000), employment growth in the last 30 years in Latin America has steadily been in services, which have accounted for $95 \%$ of net job creation in the region. ${ }^{2}$ Overall, the employment share of the services sector exceeded $54 \%$ by 1997 , with almost all of this increase

\footnotetext{
${ }^{2}$ Reinhardt and Peres (2000), building on the work of Weller (2000), show that $70 \%$ of the new jobs were created in commerce, hotels and restaurants, in social, community and personal services, in informal micro- and small enterprises where productivity and wages are generally lower than in industry, and in other services such as telecommunications and banking.
}

being at the expense of agriculture, while industry's share fell marginally. However, Katz points out that, due to the changing industrial production structure, the knowledge content of the jobs has declined, at least in that part that deals with engineering and innovation (Katz, 2000). While this may be true, multinational employers are at the same time placing more emphasis on quality labor, meaning more emphasis on basic competencies (reading, writing, communication and problem-solving skills).

Confronting globalization also means understanding the demands that the growing information and communications technology (ICT) and banking sectors will place on the supply and demand for labor. It means that workers must prepare themselves by building up competencies in order to be able to get and hold a job, or get a new job as soon as possible when job cuts take place and the demand for labor changes with the introduction of new technology. Innovation in ICT has accelerated to the point that a new technological generation is introduced every 18 months. This means that today, jobs may disappear as quickly as in one-and-a-half years, being replaced by others involving the latest technology. Another way to look at it is that for countries to compete actively for investment in ICT business they need to have highly skilled human capital that can adapt to quickly changing technology, as well as semi-skilled human capital of sufficient quality to produce good products reliably. The detailed ramifications of the effects of globalization on education and the labor market are beyond the scope of this article. The point being made here is simply that the globalizing economy places more importance than ever on education, training and basic competencies.

Finally, in order to understand the dynamics of education and the labor market in an increasingly globalized context and propose policies to deal with these problems, we need more and better quality data and also new data, especially about the Latin American and Caribbean countries. Too much of our information is based on research in the United States and the rest of the industrialized world. Latin American public and private research needs to invest more, modernize its instruments and broaden its methodologies. 


\section{II}

\section{Catching up or falling behind in human capital formation}

The human capital component of the productivity and global competitiveness equation has to be seen from a number of perspectives. One of the main constraints in Latin America has been its insufficient supply of educated, trained youth entering the workforce. First, upper secondary graduation rates need to be raised further. Second, the quality of public education needs to be dramatically improved in order for countries and individuals to compete on an equitable basis. Third, post-secondary education has to be more specifically related to the needs of the job market and national productivity. In order for countries to compete in the global economy, especially where technical innovation is concerned, Latin American universities need to be able to supply a greater number of trained scientists and engineers, especially in those fields related to the current patterns of production specialization that are evolving in several sub-regions.

Economic development is increasingly linked to a nation's ability to acquire technical knowledge, and the process of globalization is speeding up this trend. Comparative advantages are coming more and more from technical innovation and the competitive use of knowledge in those areas in which countries excel. The proportion of goods with a medium-high and high level of technology content in international trade has gone up from $33 \%$ in 1976 to $54 \%$ in 1996 (World Bank, 1999), although trade data classifications do not reflect the declining content of the engineering component in automobile manufacturing in some countries where much of the local technological content has been replaced by outside "on-line" engineering. This is especially the case with assembly operations (maquila) in the automobile industry in Mexico. Recent ECLAC studies have shown that the current pattern of production specialization and trade involves less (rather than more) domestic knowledge content. Progressing to knowledge-based societies would therefore require a significant reversal of these patterns, towards more domestic engineering and knowledge content throughout the production structure, particularly in the rapidly expanding natural resource-based export sector (Katz, 2000).

\section{Lagging competitiveness in the provision of skilled manpower}

Most countries in the Latin American and Caribbean region are falling behind their main global competitors in providing the semi-skilled and highly skilled manpower that is essential for raising their productivity and maintaining a competitive edge in the global market. The last two decades of the twentieth century have seen the newly-industrializing Asian economies (NIAE)-China, Hong Kong, Malaysia, Singapore, South Korea and Thailand- overtake the Latin American region both in secondary and tertiary education. At the same time most of the OECD countries are rapidly widening the gap with the Latin American region. ${ }^{3}$ Not only are the Latin American countries showing smaller secondary and tertiary enrollment ratios than their competitors but these ratios are also rising at a much slower pace. The Latin American skill-gap is growing rapidly, and even the developing countries of East and Southeast Asia as a whole have now overtaken the Latin American region at the secondary level. At the present rate they will overtake the Latin American region even in higher education by the end of the first quarter of the 21st century (table 1).

In most OECD countries, almost everyone now goes on to upper secondary education and the great majority, nearly $80 \%$, complete it, with Japan at $95 \%$ heading the list. In Latin America and the Caribbean, in contrast, only half go on to upper secondary education and, on average, less than a third complete it. Even in the NIAE countries, nearly $75 \%$ go on to upper secondary education. It is upper secondary education and technical education that provide the key to skilled jobs and commensurate wages for the great majority of students

\footnotetext{
${ }^{3}$ It should be noted, however, that some Latin American and Caribbean countries have higher enrollment rates than the worstperforming OECD countries. Turkey, at both the secondary and tertiary levels, and Hungary and the Czech Republic at the tertiary level still appear to do worse than, for example, Chile, Argentina, etc. However, all the countries in the region are below all the other OECD countries at both the secondary and tertiary educational levels.
} 
TABLE 1

Selected country groups: Gross enrollment in secondary and tertiary education, 1985 to $1997^{a}$

\begin{tabular}{|c|c|c|c|c|c|c|}
\hline \multirow{3}{*}{ Country groups } & \multicolumn{6}{|c|}{ Gross enrollment ratios } \\
\hline & \multicolumn{3}{|c|}{ Secondary education } & \multicolumn{3}{|c|}{ Tertiary education } \\
\hline & 1985 & 1997 & $\begin{array}{c}\text { Increase in } \\
\text { enrollment ratios } \\
\text { (in \% points) }\end{array}$ & 1985 & 1997 & $\begin{array}{c}\text { Increase in } \\
\text { enrollment ratios } \\
\text { (in \% points) }\end{array}$ \\
\hline Latin America and the Caribbean & 50.2 & 62.2 & 12.0 & 15.8 & 19.4 & 3.6 \\
\hline OECD countries & 92.3 & 108.0 & 15.7 & 39.3 & 61.1 & 21.8 \\
\hline NIAE countries ${ }^{b}$ & 57.3 & 73.1 & 15.8 & 14.8 & 30.5 & 15.7 \\
\hline East and Southeast Asia ${ }^{c}$ & 41.5 & 66.3 & 24.8 & 5.4 & 10.8 & 5.4 \\
\hline
\end{tabular}

Source: Calculated by the author on the basis of data from UNESCO (2000a).

a 1997 is the latest year for which internationally standardized regional enrollment ratios can be calculated.

b NIAE: Newly Industrialized Asian Economies (China, Hong Kong, Malaysia, Singapore, South Korea and Thailand).

c Developing countries only, including the NIAE countries.

TABLE 2

Selected country groups: human capital formation and educational performance, 1998

\begin{tabular}{|c|c|c|c|c|}
\hline \multirow{2}{*}{ Country groups } & \multicolumn{2}{|c|}{ Duration of education } & \multicolumn{2}{|c|}{$\begin{array}{l}\text { Tertiary education in natural sciences, engineering } \\
\text { and agriculture, as \% of total tertiary }\end{array}$} \\
\hline & $\begin{array}{l}\text { Compulsory } \\
\text { (years) }\end{array}$ & $\begin{array}{l}\text { Secondary } \\
\text { (years) }\end{array}$ & Enrollment & Graduates \\
\hline Latin America and the Caribbean & 7.1 & 5.1 & 26.0 & 26.6 \\
\hline OECD countries & 9.8 & 6.4 & 27.2 & 25.2 \\
\hline NIAE countries ${ }^{\mathrm{a}}$ & 7.7 & 6.3 & 36.0 & 38.2 \\
\hline East and Southeast Asia ${ }^{b}$ & 7.3 & 6.1 & 31.6 & 32.2 \\
\hline
\end{tabular}

Source: Calculated by the author on the basis of data from UNESCO (2000 a and b).

${ }^{a}$ NIAE: Newly Industrialized Asian Economies (China, Hong Kong, Malaysia, Singapore, South Korea and Thailand).

${ }^{\mathrm{b}}$ Developing countries only, including the NIAE countries.

who do not go on to university, and it is this educational level that is inadequately provided in our region.

The duration of secondary education is also shorter in the Latin America and Caribbean region than in the other competing groups by between a year and a yearand-a-half, which makes a significant difference in the amount of knowledge that can be imparted at that level. The duration of compulsory education in the region is also significantly shorter, and in many countries in the region these apparent compulsory school years still consist mainly of only half-days. The proportion of tertiary students and graduates in Latin America and the Caribbean in the critical fields of engineering, natural sciences and agriculture is also considerably lower than in the Asian groups, although it is comparable with the average proportion registered in the OECD countries (table 2).

\section{Basic competencies for the workplace}

"An untrained worker may have valuable talents, but those
talents must be certified by the 'educational establishment'
before a company can afford to use them"

(AKERLOF, 1970).

There is a growing recognition of the need to measure skill and human capital more meaningfully than by merely taking the number of years of educational attainment or fairly broad classifications of levels of educational attainment, which measure duration but not 
content or quality. ${ }^{4}$ More than 20 countries have tried to define and measure acquired competencies through their participation in the International Adult Literacy Survey, which has collected high-quality internationally comparable information on the level and distribution of basic competencies in the adult population. The functional adult literacy data from these countries, which account for more than $50 \%$ of the world's gross domestic product, make an important contribution to an understanding of the demand and supply of skills in the current global, knowledge-based economy (OECD, 2000a).

These measurements show very dramatically that in every country surveyed low functional adult literacy is a much larger problem than previously assumed, at a time of increasing skill demands in the labor market. They also show that, across countries, higher levels of literacy skills in the workforce are associated with larger proportions of knowledge jobs in the economy. It should be noted that the concept of literacy now includes not only knowing how to read and write but also the basic skills needed for understanding and using information contained in texts and documents, carrying out arithmetical operations, and communication and problem-solving. The basic literacy skills positively influence the probability of being in a highly-skilled white-collar position and negatively affect the probability of being unemployed or occupying a bluecollar position, and this conclusion is supported by evidence from the study of occupational categories by industrial sectors. The impact of improved functional literacy, especially in highly-skilled white-collar occupations, differs according to the level of educational attainment of the individuals concerned, and the benefits accruing from improved literacy skills are even higher for workers with tertiary education than those with only secondary education.

Of the factors studied in the analysis of wages, educational attainment is one of the most important determinants of earnings in most countries, even when variations in the other factors are held constant. Literacy proficiency also has a substantial effect on earnings in many of the countries studied, although there are major differences among countries in the strength of these relationships. The effect of literacy skills on earnings depends in part on the differences in levels of education,

\footnotetext{
${ }^{4}$ The main classification is the International Standard Classification of Education (ISCED-97), which is the internationally recognized standard for classifying levels of educational attainment (see table 7 and footnotes 6 and 7).
}

but in many countries literacy also has an independent, net effect on wages. There are large differences between countries in how much their labor markets reward education and how much they pay for skills and experience, as these rewards are amplified or attenuated by the relative conditions of supply and demand.

In this respect, the experience of Chile, as the first Latin American country to measure itself and publish its results, is sobering and shows the very large gap in basic competencies as well as the large internal inequalities that will need to be corrected. The message for the present and the future is the need to improve the quality and equity of public education and to inculcate the habit of lifelong learning in adults' working and private lives (Bravo and Contreras, 2001).

A number of countries have tried to combine basic competencies in the workplace with formal educational programmes. Australia has introduced national competence standards and Canada has developed a method for the assessment of prior learning and the setting of standards, both with the joint involvement of the educational community, business, labor and the federal and state governments. Prior learning assessments are based on the assumption that the acquisition of knowledge and skills may take place not only through formal education courses but also through work experience, community and volunteer work, and independent study. Adults who demonstrate that they have achieved a well-defined skill level may be given formal credits that will help them to enroll on a school or college course, or a certificate that can be used in the labor market.

France has established Assessment Centres and the United Kingdom has designed a system of National Vocational Qualifications (OECD, 1996). The UK system has had a profound impact on competence assessment and certification methods, covering not only the traditional fields of vocational training but also broad sections of the labor market and the working population. However, the OECD analysis used in this article still relies on the ISCED levels of educational attainment for the purpose of making international comparisons.

Attention to the incoming cohorts of workers constitutes an important planning priority for the future. The first global survey of the key skills of teenagers recently released by the OECD compares more than 250,00015 -year-olds in 32 countries ( 27 OECD countries) as regards their knowledge of reading, mathematics and science. Mexico and Brazil participated in this first Programme for International Student Assessment (PISA) and ranked last in all three areas, and significantly below 
all other countries in mathematics and science, even though three of the countries participating (Poland, Russia and Latvia) have comparable levels of per capita GDP (OECD, 2001a). These outcomes reconfirm the need to better educate youth in the region, and point to the deficient areas. At the same time, it is important to undertake further comparative research and try to identify the relative importance of the various causes of poor performance, particularly in the case of countries with similar levels of educational investment producing very different levels of performance.
In addition to preparing future workers, the public and private sectors need to be attentive to the retraining and productivity of older workers already in the labor force. The ability of older workers to learn new skills is an important determinant of their continuing productivity, and especially their ability to keep up with modernizing industrial and occupational structures. This is a critical labor market issue when one takes into account the significantly increasing longevity and demographic aging of the population in Latin America.

\section{III}

\section{Secondary and higher education policies and the labor market: what is to be done?}

The main challenge for the Latin American and Caribbean countries is to keep children in school up to their upper secondary graduation. Raising retention rates in the upper secondary level will have the greatest impact in the short term. Low transition rates from primary to lower secondary and lower secondary to upper secondary are the biggest problems currently confronting public education. The transition from school to work and the labor force participation of young people 15 to 29 years of age, both while they continue their education and after completion of their initial education, are also important issues in Latin American countries. Rising skill requirements of labor markets, an increase in unemployment in recent years and higher economic expectations of individuals and societies have given rise to growing regional concern with the need to put more emphasis on technical and vocational programmes in upper secondary and higher education.

\section{Vocational and work-based training}

Increasingly, upper secondary education is seen to be as much a route to obtaining skilled and well-paid employment as getting a place in a university. Rising skill demands are making an upper secondary qualification the minimum credential for successful labor market entry. The average situation in the OECD is that half of upper secondary students are now attending vocational technical or apprenticeship programmes, although Spain and Portugal, as well as Japan, do not follow this pattern (table 3). In the Latin American countries the main emphasis is still on general educational programmes. The exceptions are Chile and Argentina, where over $40 \%$ of upper secondary students attend technical and vocational courses (a higher figure than that for Spain, Portugal and Japan). Upper secondary technical education has important historical and cultural foundations, as may be seen from the similarity between Latin American countries and the two countries of the Iberian peninsula. In the OECD countries, an average of one-sixth of upper secondary students taking technical/vocational courses or serving apprenticeships receive training that is both schoolbased and work-based, although once again there are important exceptions like the United Kingdom, Japan and Portugal, where this category does not exist at all, or Spain, where it is very small.

One of the best examples of training for the labor market is the German dual apprenticeship system. Developing dual-system apprenticeship programmes at the upper secondary level that are suitably adapted to national circumstances could be a concrete way of expanding technical education in Latin American countries and improving the supply of the necessary skilled labor in the region. In Latin America, however, the dual-system apprenticeship programmes that are common in Germany, Switzerland and the Netherlands, 
TABLE 3

Latin America and selected OECD countries: Enrollment in technical and vocational programmes at the upper secondary level (1999) ${ }^{a}$

\begin{tabular}{|c|c|c|c|c|}
\hline \multirow{2}{*}{ Country } & \multirow{2}{*}{$\begin{array}{l}\text { Upper secondary } \\
\text { graduates }{ }^{b}\end{array}$} & \multicolumn{3}{|c|}{$\begin{array}{l}\text { Distribution of enrollment at upper secondary } \\
\text { level, by programme orientation }\end{array}$} \\
\hline & & General & Technical/ vocational & Of which part work-based \\
\hline Japan & 95 & 74 & 26 & $\mathrm{c}$ \\
\hline Germany $^{\mathrm{d}}$ & 92 & 35 & 65 & 49 \\
\hline Netherlands & 92 & 33 & 67 & 20 \\
\hline United Kingdom & .. & 33 & 67 & $\mathrm{c}$ \\
\hline Switzerland & 83 & 35 & 65 & 57 \\
\hline OECD country mean & 79 & 49 & 51 & 16 \\
\hline United States & 78 & .. & .. & .. \\
\hline Spain & 73 & 69 & 31 & 5 \\
\hline Portugal & .. & 75 & 25 & $\mathrm{c}$ \\
\hline Peru $^{\mathrm{d}}$ & 57 & 76 & 24 & 0 \\
\hline Chile $^{\mathrm{d}}$ & 56 & 58 & 42 & 1 \\
\hline Brazil $^{\mathrm{d}, \mathrm{e}}$ & 44 & 70 & 30 & .. \\
\hline Argentina $^{\mathrm{d}}$ & 40 & 57 & 43 & 0 \\
\hline Uruguayd & .. & 81 & 19 & .. \\
\hline Mexico & 31 & 86 & 14 & $\mathrm{c}$ \\
\hline Paraguay $^{\mathrm{d}}$ & 31 & 84 & 16 & $\mathrm{c}$ \\
\hline
\end{tabular}

Source: Calculated by the author on the basis of OECD (2000b and 2001b).

a Includes public and private institutions and full-time and part-time students.

${ }^{\mathrm{b}}$ Upper secondary graduates as a percentage of typical age of graduation.

c Not applicable.

d 1998.

e Brazil has a three-year single level secondary programme.

with their highly developed guild systems, hardly appear to exist except in Chile. ${ }^{5}$ Experimentation in this field should be encouraged in search of suitable "localized" ways of adapting the apprentice system to the idiosyncrasies of the Latin American societies. In Chile, for example, the lack of employers' insurance to cover accidents suffered by students in on-the-job workstudy programmes is a major barrier to the willingness of firms to participate in such programmes, especially for small and medium-sized enterprises, which have the potential to offer many more work-study opportunities. A simple agreement establishing a government-backed insurance scheme would be an enormous step forward.

\section{Raising retention rates in upper secondary education}

In Latin America, the proportion of students who survive to graduate from upper secondary education is

${ }^{5}$ For a comprehensive evaluation of Chile's dual-system experience, see Bravo and others (2001). rarely more than half of the similar survival rate in the OECD countries, and they also spend fewer years being trained at that level. Each country will decide its own education priorities, but upper secondary education should be one of the priority concerns of countries that wish to be competitive in the global economy by raising national skill levels in a way that will not increase -and might even decrease- the overall inequality of the educational systems of the region. The Latin American countries are falling behind in the critical task of expanding upper secondary education and nonuniversity tertiary education, which is the main means of producing a skilled labor force to man the industrial, agricultural and service sectors. It goes without saying that all individuals should have an equal opportunity to pursue education as far as they wish and that access to a full secondary education should be a basic right for all, as it already is in industrialized countries.

The Argentine educational situation neatly sums up the challenge. Argentina's educational system is one of the most advanced in the region, and in a number of aspects equals that of the OECD countries. However, it has very low retention rates. A recent cohort analysis 
shows that out of 100 students entering primary school, 84 will enter the seventh grade, 76 will enter the ninth grade, 40 will enter the last year of secondary school, 35 will enroll in university and only seven will graduate. (World Bank, 2000).

Latin America needs to make a great leap forward in raising secondary graduation rates, providing technical training opportunities linked with secondary education, and improving the quality and relevance of higher education with special attention to university programmes in the natural and applied sciences and engineering. Higher education systems must adapt to meet the changing needs of industry and services. Effective labor market feedback mechanisms, such as tracer surveys and regular consultations with employers and alumni, are needed for the purpose of adjusting curricula. In Denmark, for example, industry representatives, including presidents of large companies, commonly sit on the departmental boards of universities to advise them on training and research priorities (Salmi, 2001) and this also occurs in Mexico's new two-year technological institutions (Castro and Levy, 2000).

\section{Curing the de-professionalization of higher education}

Castro and Levy describe what they call the "deprofessionalization of higher education", by which they mean the result of large increases in enrollment producing more job candidates than the market can handle, so that graduates take up whatever jobs they can find because they cannot find jobs corresponding to their diplomas. Among secondary students who proceed directly to the job market, those who were in technical programmes take up technical occupations requiring more than primary education but where the specific skills that are required could be learned through work experience. Other students from both tracks obtain qualifications that allow entry into higher education that concentrates on professions that lead to specific jobs, e.g. law, engineering, medicine, etc. ${ }^{6}$ This remains the basic model under which most public policy is designed. However well it worked for many years, graduates at all levels now largely outpace the expansion of the labor market, and the neat assumptions of this model are breaking down.

\footnotetext{
${ }^{6}$ See Castro and Levy (2000) for a clear-sighted analysis of higher education policies in Latin America and recommendations for change that will result in an educational system providing more flexible, relevant and efficient educational opportunities, more responsive to the needs of a globalizing labor market.
}

When graduates of higher education cannot find jobs related to their education, their professional degrees nevertheless help them gain better employment than that gained by those who do not have higher education, and they take over much of the market for occupations previously filled by secondary level graduates. Thus, because higher education degrees pay off, many graduates of technical schools disregard their technical skills and try to use their technical diplomas to enter higher education because the education premiums in terms of earnings for tertiary university graduates are significantly higher. However, this fact cannot be seen in isolation, particularly in Latin American countries, where higher educational attainment is frequently associated, at least at the present time, with higher unemployment. Although education is among the most importance considerations in improving micro policies in Latin American countries, education policies and actions need to be part of an integrated package of micro reforms, which should include on the demand side the correct environment for higher productivity job creation.

Castro and Levy propose two possible solutions to the problem of de-professionalization, each already being applied but needing more recognition and appropriate public policy to become effective. The first introduces "general higher education" as a formal higher education option to complement the specific so-called "professional education" options in the fields of law, economics and other professional studies leading to professional careers in these areas. The advantage this change provides is that it takes the pressure off the universities to teach students in professions that they do not intend or cannot be equipped to pursue, thereby reducing the resources needed to meet the demand for university training in these fields and providing a more realistic supply of graduates to those professions. The general higher education option develops skills in writing, reading, mathematics and problem solving and responds to broader humanistic, cultural, social, and political rationales for producing more educated citizens. It fits in well with a market for managerial and servicesector occupations in which the services sector alone accounted for $58 \%$ of the labor force in Latin America and the Caribbean in 1999 (World Bank, 2000). In effect, this option elevates what had been considered a secondary school responsibility to the level of higher education, in recognition of the increasing knowledge, reasoning capacity and judgment required for working in an increasingly knowledge-based economy.

The second solution is to elevate training for technical occupations to the post-secondary level, as 
has been done with associate degrees at community colleges in the United States, diplomas at polytechnics (now university colleges) in the United Kingdom, and parallel forms in other industrialized countries. Secondary education would cease to carry the burden of technical or vocational skills that are not wanted by the students, giving them the option to enroll in the post-secondary option in order to seek the specific technical skills that they wish to develop for particular labor markets. These courses are growing faster than conventional four-year courses in industrial countries and in some Latin American countries like Argentina and Chile. At the same time, they allow secondary education to focus on its task of giving a higher quality general education to prepare students for the labor market and to carry out their roles as involved, informed citizens and parents.
In this author's view, however, Castro and Levy's proposal needs to be more flexible. Latin American countries must offer their students the option of technical/vocational training at the upper secondary level precisely because only a small proportion of these students continue with post-secondary schooling or higher education, either because they do not wish to or because they cannot afford to and must go to work. In many Latin American countries, the need to work is already a barrier to keeping young people in upper secondary education until they graduate. This raises a further and separate question that merits consideration in policy formulation: namely, the establishment of income subsidies for students to allow them to pursue their education, whether through means-tested grants, no-interest or low-interest educational loans, or workstudy financing.

\section{IV}

\section{Does more education lead to higher earnings? A look at the evidence from education premiums}

The impact of education and training on labor market performance is still imperfectly measured. Typically, wages are used as an indicator, as is done in the following series of analyses. This is based on the assumption that superior performance in the workplace will be rewarded by higher wages and that earnings differentials by levels of educational attainment are a measure of the financial incentives in a particular country to invest in further education (OECD, 1997). However, there are obvious limitations to this assumption. Earnings differentials may also reflect differences in the supply of and barriers to access to educational programmes at different levels. Wages are driven as much by occupational choice as by performance within an occupation, and the best teacher still earns less than a mediocre football player. Wage differentials by educational level also reflect the financial incentives in a country for investment in education (see the example of Argentina given later) as much as the effect of the education and training system on labor market success (Amjad, Reboani and Sziraczki, 2001).

Nonetheless, earnings data are one of the few labor market indicators that are regularly and reliably collected and, in this analysis, countries are not compared directly to each other. Indexes of the earnings of other levels of education as compared with upper secondary education earnings, separately for men and women, were constructed for five Latin American countries -Argentina, Brazil, Chile, Paraguay and Uruguay- on the basis of the two latest household surveys carried out in each of these countries. ${ }^{7}$ Since these indexes are based on earnings differentials within a country, they exclude the effects of exchange rates and inflation, thus making possible a better comparison of earnings differentials among countries, although other explanatory variables like income differences between sectors remain. In order to understand better the more recent experience of younger workers in the labor market, it is useful to perform the same analysis for all wage earners ( 15 to 64 years) and for the younger age group (25 to 34$)$. Tables 4 and 5 show the earnings premiums for these two age groups.

\footnotetext{
${ }^{7}$ Analysis and calculations by the author, on the basis of special tabulations by the ECLAC Division of Statistics and Economic Projections of data from household surveys of the respective countries.
} 
Latin America (five countries): Education premiums in terms of higher earnings for persons aged 15 to 64, by level of educational attainment and gender, 1993-1999 (Index for upper secondary education $=100$ )

\begin{tabular}{|c|c|c|c|c|c|c|c|c|c|c|c|}
\hline \multicolumn{2}{|c|}{ Level of educational attainment } & \multicolumn{2}{|c|}{ Argentina } & \multicolumn{2}{|c|}{ Brazil } & \multicolumn{2}{|c|}{ Chile } & \multicolumn{2}{|c|}{ Paraguay } & \multicolumn{2}{|c|}{ Uruguay } \\
\hline & & 1994 & 1999 & 1993 & 1999 & 1996 & 1999 & 1994 & 1999 & 1994 & 1999 \\
\hline \multirow{2}{*}{$\begin{array}{l}\text { Below upper } \\
\text { secondary }\end{array}$} & Male & 65 & 64 & 44 & 52 & 70 & 61 & 53 & 63 & 63 & 63 \\
\hline & Female & 63 & 62 & 45 & 52 & 71 & 60 & 33 & 58 & 64 & 62 \\
\hline \multirow{2}{*}{$\begin{array}{l}\text { Upper } \\
\text { secondary }\end{array}$} & Male & 100 & 100 & 100 & 100 & 100 & 100 & 100 & 100 & 100 & 100 \\
\hline & Female & 100 & 100 & 100 & 100 & 100 & 100 & 100 & 100 & 100 & 100 \\
\hline \multirow{2}{*}{$\begin{array}{l}\text { Non-university } \\
\text { tertiary }\end{array}$} & Male & 98 & 139 & . & .. & 139 & 118 & .. & 118 & .. & 121 \\
\hline & Female & 90 & 123 & .. & .. & 108 & 112 & 116 & 132 & .. & 133 \\
\hline \multirow{2}{*}{ University tertiary } & Male & 166 & 203 & $259^{\mathrm{a}}$ & $270^{\mathrm{a}}$ & 296 & 279 & 228 & 217 & 188 & 196 \\
\hline & Female & 176 & 177 & $233^{a}$ & $272^{a}$ & 224 & 224 & 189 & 214 & 173 & 181 \\
\hline
\end{tabular}

Source: Calculated by the author on the basis of special tabulations of household survey data by the ECLAC Division of Statistics and Economic Projections.

a Includes university and non-university tertiary levels.

TABLE 5

Latin America (five countries): Education premiums in terms of higher earnings for persons aged 25 to 34, by level of educational attainment and gender, 1993-1999 (Index for upper secondary education $=100$ )

\begin{tabular}{|c|c|c|c|c|c|c|c|c|c|c|c|}
\hline \multicolumn{2}{|c|}{ Level of educational attainment } & \multicolumn{2}{|c|}{ Argentina } & \multicolumn{2}{|c|}{ Brazil } & \multicolumn{2}{|c|}{ Chile } & \multicolumn{2}{|c|}{ Paraguay } & \multicolumn{2}{|c|}{ Uruguay } \\
\hline & & 1994 & 1999 & 1993 & 1999 & 1996 & 1999 & 1994 & 1999 & 1994 & 1999 \\
\hline \multirow{2}{*}{$\begin{array}{l}\text { Below upper } \\
\text { secondary }\end{array}$} & Male & 72 & 71 & 53 & 55 & 64 & 72 & 75 & 64 & 71 & 72 \\
\hline & Female & 69 & 63 & 48 & 56 & 64 & 60 & 64 & 59 & 60 & 55 \\
\hline \multirow{2}{*}{$\begin{array}{l}\text { Upper } \\
\text { secondary }\end{array}$} & Male & 100 & 100 & 100 & 100 & 100 & 100 & 100 & 100 & 100 & 100 \\
\hline & Female & 100 & 100 & 100 & 100 & 100 & 100 & 100 & 100 & 100 & 100 \\
\hline \multirow{2}{*}{$\begin{array}{l}\text { Non-university } \\
\text { tertiary }\end{array}$} & Male & 98 & 131 & .. & $\cdot$ & 127 & 132 & & 100 & .. & 130 \\
\hline & Female & 96 & 137 & .. & .. & 119 & 128 & 102 & 132 & .. & 110 \\
\hline \multirow{2}{*}{$\begin{array}{l}\text { University } \\
\text { tertiary }\end{array}$} & Male & 164 & 177 & $212^{\mathrm{a}}$ & $225^{\mathrm{a}}$ & 200 & 267 & 181 & 177 & 144 & 147 \\
\hline & Female & 208 & 168 & $215^{\mathrm{a}}$ & $242^{\mathrm{a}}$ & 242 & 247 & 170 & 229 & 134 & 159 \\
\hline
\end{tabular}

Source: Calculated by the author on the basis of special tabulations of household survey data by the ECLAC Division of Statistics and Economic Projections.

${ }^{a}$ Includes university and non-university tertiary levels.

How do wages of all wage earners differ by level of education, separately for men and women? For the most part, there is a strong relationship between educational attainment and earnings of workers aged between 15 and 64 in the five Latin American countries studied. In all the countries in question, university graduates earn considerably more than upper secondary graduates, who were used as the benchmark for the education premium calculations. Chile and Brazil show the greatest university education premiums, although the Brazilian figures include both university and nonuniversity tertiary graduates, while Uruguay and Argentina show the smallest premiums. The current premiums range from $179 \%$ for men in Chile down to $77 \%$ for women in Argentina. Almost all these premiums increased in the relatively short period between the two surveys and are usually higher for men than for women.

There are also large education premiums for upper secondary graduates, although they are not as large as 
those for university graduates. In Brazil the earning capacity of a student is nearly doubled by completing upper secondary education and in the other countries it is increased by at least a third. Completing upper secondary education is clearly recognized as the starting point for earning higher wages, and these premiums increased between the two surveys in Argentina, Chile and Uruguay. The premiums are also consistently higher for women than men, which is somewhat surprising but might reflect the growing demand for female secretarial and other service staff.

The differential earnings patterns for the young working population aged 25 to 34 , as shown in table 5 , are very different from those of the working population as a whole. The most significant difference is that the current education premiums for university education for this younger age group are still considerably lower than for the working population as a whole, as was also the case with the data from household surveys in the early 1990s. The education premiums of this younger age group have almost all gone up over the last five years but have not caught up with the overall education premiums, which have also increased. The main exception to this pattern is Argentina, where the last five years of economic crisis and severe recession are reflected in the dramatic decline in the returns to education for young women workers with university education, which have fallen by $20 \%$ over that period.

The premiums for upper secondary education for young workers have not changed very much. For all countries these premiums are less than for the working population as a whole, probably because most of the young people who have not reached the upper secondary level will have completed the primary cycle and may have completed the lower secondary, whereas in the working population as a whole there will still be a large block which has not completed the primary level. The premiums are all higher for women than men (except in Brazil), and they are significantly higher in Chile and Uruguay.

To sum up, education premiums for the young working population aged 25 to 34 have almost all increased at all education levels, but three-quarters of them are still below those for the total working population with the same educational qualification. This is not all that surprising, as the older populations are also rewarded for experience. The biggest increases have been at the university level. It is recommended that these "returns to education" analyses be carried out on a regular basis and over longer time periods for as many countries in the ECLAC region as can provide comparable data from their national household survey programmes.

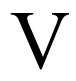

\section{Are gender disparities being reduced? What does the evidence from earnings differentials tell us?}

\begin{abstract}
Although both men and women with upper secondary or tertiary educational attainment levels have substantial earnings advantages compared to those who have not completed their secondary education, there remain very large earnings differentials between men and women with the same level of educational attainment. Table 6 presents these male-female earnings disparities for the working population 15 to 64 years of age and also for the young age group 25 to 34 years of age in order to determine more precisely if these disparities might be diminishing. ${ }^{8}$
\end{abstract}

\footnotetext{
${ }^{8}$ It would have been preferable to use the 25 to 29 age group, because it better represents recently acquired educational attainment levels and reflects the more recent education reform policies, but the survey samples were too small to make this comparison.
}

As might be expected and is common throughout the world, negative earnings disparities between men and women with the same educational qualifications exist in Latin America for all the countries analysed and at all educational levels. These disparities range from those observed in the case of young upper secondary graduates in Brazil, where on average women still earn only $44 \%$ of the average man's wage, to persons of the same educational level in Paraguay, where on average women now earn $75 \%$ of the average man's wage. The current earnings disparities are fairly consistent throughout the educational levels, as is their range (table 6).

What was not expected is the number of cases where these gender disparities have increased in the 
TABLE 6

Latin America (five countries): Mean annual earnings of women as a percentage of mean annual earnings of men, by age group and level of educational attainment, 1993-1999

\begin{tabular}{|c|c|c|c|c|c|c|c|c|c|c|c|}
\hline \multirow[t]{2}{*}{ Level of educational attainment } & \multirow{2}{*}{$\begin{array}{l}\text { Age } \\
\text { group }\end{array}$} & \multicolumn{2}{|c|}{ Argentina } & \multicolumn{2}{|c|}{ Brazil } & \multicolumn{2}{|c|}{ Chile } & \multicolumn{2}{|c|}{ Paraguay } & \multicolumn{2}{|c|}{ Uruguay } \\
\hline & & 1994 & 1999 & 1993 & 1999 & 1996 & 1999 & 1994 & 1999 & 1994 & 1999 \\
\hline Below upper & $25-34$ & 66 & 62 & 51 & 46 & 77 & 60 & 59 & 68 & 56 & 52 \\
\hline secondary & $15-64$ & & 62 & & 55 & & 66 & & 67 & & 61 \\
\hline Upper & $25-34$ & 70 & 69 & 55 & 44 & 76 & 72 & 77 & 75 & 65 & 68 \\
\hline secondary & $15-64$ & & 64 & & 56 & & 71 & & 73 & & 62 \\
\hline Non-university & $25-34$ & 72 & 72 & .. & .. & 63 & 70 & 64 &.. & 62 & 57 \\
\hline tertiary & $15-64$ & & 57 & & .. & & 67 & &.. & & 69 \\
\hline University & $25-34$ & .. & 66 & $57^{\mathrm{a}}$ & $48^{\mathrm{a}}$ & 70 & 67 & 68 & .. & .. & 74 \\
\hline tertiary & $15-64$ & & 56 & & $56^{\mathrm{a}}$ & & 57 & & 72 & & 58 \\
\hline
\end{tabular}

Source: Calculated by the author on the basis of special tabulations of household survey data by the ECLAC Division of Statistics and Economic Projections.

${ }^{a}$ Includes university and non-university tertiary.

young working population since the previous set of surveys three to five years ago. Of the 15 disparity calculations for young workers that it was possible to make for two points in time, these already large female-male earnings disparities have increased in 11 cases and decreased only in three. Even at the university level, the two disparities that it was possible to track over recent years, in Brazil and Chile, have got worse. At the same time, however, the earnings disparities by gender for the 25 to 34 age group are often less than the corresponding disparities among the total working population (age 15 to 64). Out of the 17 possible comparisons, the younger workers registered a smaller earnings disparity in 10 cases and a greater disparity in six. Although there has been a generational improvement, the most recent trends among young workers are discouraging. What is particularly disturbing is the fact that earnings disparities by gender have increased at all educational levels.

In conclusion, the disparity between women's and men's earnings among workers with the same educational qualifications continues to exist and has even been growing in recent years. There has been a moderate generational improvement in this respect, but the recent worsening in the disparities among younger workers suggests that this generational change is not being transmitted to new entrants into the labor market, particularly in the context of an economic slowdown and increasing globalization.

\section{VI}

\section{In Latin America, more education does not guarantee a higher probability of employment}

Conventional wisdom holds that education is positively correlated with employment and earnings and that better-educated people are more likely to have jobs and, if economically active, less likely to be unemployed (Centre for Educational Research and Innovation (CERI), 2001b). Labor force participation rates almost invariably rise with higher educational attainment, and this applies equally to the OECD and the Latin American countries (OECD, 2000a). Rates of earnings also usually rise in Latin America, although differentially, with higher educational attainment. This is to be expected, as both the OECD and Latin American economies are 
TABLE 7

Latin America (five countries): Unemployment rates by level of educational attainment in 1998 for persons aged 25 to 64

\begin{tabular}{|c|c|c|c|c|c|}
\hline \multirow{3}{*}{ Country } & \multicolumn{5}{|c|}{ Unemployment by level of educational attainment } \\
\hline & & \multirow{2}{*}{$\begin{array}{l}\text { Below upper } \\
\text { secondary } \\
(\%)\end{array}$} & \multirow{2}{*}{$\begin{array}{c}\text { Upper secondary and } \\
\text { non-tertiary post secondary } \\
(\%)\end{array}$} & \multicolumn{2}{|c|}{ Tertiary } \\
\hline & & & & $\begin{array}{c}\text { type } \mathrm{B}^{\mathrm{a}} \\
(\%)\end{array}$ & $\begin{array}{c}\text { type } A^{b} \\
(\%)\end{array}$ \\
\hline \multirow[t]{2}{*}{ Brazil } & Men & 5.9 & 4.7 & 2.7 & 3.7 \\
\hline & Women & 12.5 & 9.0 & 3.4 & 1.5 \\
\hline \multirow[t]{2}{*}{ Chile } & Men & 4.7 & 4.1 & 5.6 & 2.4 \\
\hline & Women & 3.6 & 5.0 & 7.7 & 2.3 \\
\hline \multirow[t]{2}{*}{ Mexico } & Men & 1.7 & 2.0 & 2.1 & 2.4 \\
\hline & Women & 3.3 & 4.6 & 1.9 & 2.6 \\
\hline \multirow[t]{2}{*}{ Paraguay } & Men & 2.6 & 2.8 & 3.5 & 2.8 \\
\hline & Women & 5.5 & 4.5 & 2.5 & 2.7 \\
\hline \multirow[t]{2}{*}{ Uruguay } & Men & 5.4 & 5.2 & .. & $1.4^{\mathrm{c}}$ \\
\hline & Women & 12.8 & 8.7 & .. & $2.7^{\mathrm{c}}$ \\
\hline OECD & Men & 8.9 & 5.3 & 4.3 & 3.3 \\
\hline country mean & Women & 10.0 & 7.6 & 5.2 & 4.6 \\
\hline
\end{tabular}

Source: Calculated by the author on the basis of data from OECD (2000b).

a Type B tertiary programmes are typically shorter than type A programmes and focus on practical, technical or occupational skills for direct entry into the labour market, although some theoretical foundations may be covered. They have a minimum duration of two years full-time equivalent.

${ }^{b}$ Type A tertiary programmes are largely theory-based and are designed to provide sufficient qualifications to advance to research programmes and professions with high skill requirements. They have a minimum duration of three years full-time equivalent, although they typically last four or more years. They also include postgraduate programmes like a Master's degree.

${ }^{c}$ Includes both type A and type B tertiary programmes.

becoming increasingly dependent on a stable supply of well-educated workers to further their economic development and maintain their competitiveness.

But the patterns in Latin American countries are not similar to those of the OECD economies in the case of unemployment (table 7). Only $8 \%$ of the national unemployment rates disaggregated by educational level and gender that go to make up this OECD average showed unemployment rates rising with higher educational attainment. In contrast, more than $40 \%$ (16 out of 28) of the available disaggregated national unemployment rates in the Latin American countries showed unemployment rates which rose, instead of falling, with higher educational attainment. This is not an isolated or new phenomenon. Earlier figures for 1996, which covered only three countries in the Latin American region, showed that half of the available disaggregated unemployment rates rose with higher educational attainment (OECD, 2000c).

There appears to be a serious mismatch in the region between the actual or perceived adequacy of working skills and the capacity of the labor market to supply jobs that match those skills. This raises critical issues for policy makers in the region both on the education side and the labor market side. This is a very pertinent current issue in Latin America as a whole in view of its growing unemployment, now approaching $9 \%$ (Ocampo, 2001). It should be noted that this analysis does not compare unemployment rates per se but concerns the differentials in unemployment rates by level of education within each country. ${ }^{9}$ This withincountry disparity analysis avoids many of the problems that occur when national rates are compared. It would be useful to attempt to estimate the degree of underrecording of unemployment in Latin American countries in order to sharpen the picture of the labor market situation.

\footnotetext{
${ }^{9}$ Low unemployment rates in a country may reflect the underregistration of people looking for work, particularly if unemployment benefits are not provided or if the unemployment definitions that are used are restrictive. For a more detailed discussion of these issues in Latin America, see Weller (2000), OECD (2001c) and OECD (1997).
} 


\section{VII}

\section{Measurement: the key to evidence-based research}

A key ingredient for informed policy-making is quantitative analysis, and the prerequisite for that is statistical measurement, whether from government, international or private sector sources. The data used in this article provide valuable comparable information about the status of education and its relation to labor market performance in the general population, which will be extremely useful for developing and monitoring major policies (for example, for determining the priorities in education reform). Despite their limitations, these data are sufficient to provide meaningful measurements for these broad purposes in countries with solid national household survey data that have been standardized into internationally comparable education and labor market indicators. But more work needs to be done to improve national household surveys and develop indicators in Latin American and Caribbean countries in order to make the determination of the education premiums accruing to different levels of education by age, gender and, as far as possible, occupation, a standard practice based on generally recognized methodologies. Increased investment in business registers and improved enterprise-level surveys with emphasis on the labor component are needed. At the simplest level this involves placing well-designed questions about the characteristics and quality of the labor force of firms within existing enterprise/industrial survey programmes of national governments in order to improve our understanding of the contribution of human capital to productivity and growth.

Important gaps still persist in education, training and labor statistics, which handicap the in-depth study of the relationship between work and education and training. National data collection programmes in Latin American countries do not provide the necessary micro data and analyses that are needed to understand education and labor market dynamics within countries and especially to promote actions in the short term. Measurement methodologies have not kept pace with innovations and evolution in the production sector. A great deal of turbulence lies underneath the often seemingly benign aggregate rates of employment, unemployment or earnings that may mask Schumpeterian processes of creative destruction and the impact of the business cycle. ${ }^{10}$ While industry's overall share in employment has only changed marginally over the last 30 years (from $23.1 \%$ in 1970 to $21.4 \%$ in 1997 , according to Katz), more highly-skilled local jobs with engineering and technological content have been systematically replaced by less-skilled jobs involving the assembly of imported components (Katz, 2000). Better measurement of these processes is needed in order to understand them more fully.

Getting and keeping a job is becoming harder in today's globalized world, yet not enough is known about the impact of free trade, market liberalization, national regulatory structures and other factors on the prospects for people of different levels of education and skills to stay in employment, with growing wages and job security. A great deal of further work is needed to examine the microeconomics of education, skills and the labor market. More advantage needs to be taken of private sector data, as for example by compiling information on job cuts, as is done somewhat more systematically in the OECD countries.

The research agenda needs to provide for proper monitoring of the performance of the education system, its students and adult competencies. Every country in the region, using accepted, standardized indicators, should be able to report on its education system and be able to compare itself with other countries in Latin America and the Caribbean and other countries and regions in the world. Likewise, every country in the region should strive to measure the basic competencies for the workplace of its adult population, using accepted

\footnotetext{
${ }^{10}$ Schumpeter (1950) defined what he called a "process of creative destruction", asserting that the essential point of capitalism is that it is an evolutionary process of economic change that is never by its nature stationary. The net result is a process which "creatively destroys" existing structures (firms/employment) through competition from new commodities, new technologies, new sources of supply, and new types of industrial organization. He points out that this is not a question of price competition but is much more fundamental - the existing product/service is destroyed to be replaced by the new one. This is competition as we know it today in the information and telecommunications technology sector and which is exacerbated by the additional factors of concentration, firm size and globalization.
} 
international standards, in order to find out where corrective action is needed. They should also strive to establish systems of certification of the competencies of teachers, students and the labor force in general.

\section{VIII}

\section{Conclusions and policy agenda}

\section{Conclusions}

Although education is of the first importance in improving microeconomic policies in Latin American countries, education policies and actions need to be part of an integrated package of micro reforms, which include on the demand side the establishment of a suitable environment for the creation of higherproductivity jobs. In confronting globalization, it is employment (and unemployment, of course) that provides the nexus between the macroeconomic aspects of globalization, trade and other policies and the micro or human dimensions of globalization such as job creation, job security, and wage employment, which are the main channels through which incomes are determined and income distribution is changed. Add to this the related employment factors of social protection, access to quality education and training, and health care.

Despite very large investments in education reform, the Latin American countries are still falling behind their competitors in human capital formation, especially as regards the upper secondary level and technical education. The pattern of positive labor market returns to education, which is fairly consistent throughout the OECD countries, is much more mixed in Latin America, and in a number of cases it is even negative. In the OECD countries only $8 \%$ of the national unemployment rates by educational level and gender reflect unemployment rates that rise with higher educational attainment. In contrast, the comparable figure is more than $40 \%$ in the Latin American countries, where unemployment rates often rise rather than fall with higher educational attainment. There appears to be a serious mismatch in the region between the actual or perceived adequacy of working skills and the capacity of the labor market to supply jobs that match those skills. For those who do have jobs, however, there is a very clear and positive education premium, rising with the level of education. Thus, an upper secondary certificate makes a big difference but a university degree makes an enormous difference, both for men and women and for older and younger workers alike (see tables 4 and 5).

We also see that there are still very large earnings differentials between men and women with the same level of educational attainment. An unexpected finding is that in the young working population these gender disparities have increased since the previous set of surveys three to five years ago. Thus, the disparity between the earnings of men and women with the same educational qualifications continues to be with us and has even been growing in recent years.

Obtaining more and better education is one of the most important actions that workers can take to prepare themselves to confront globalization. While this is not sufficient in itself, it is becoming more and more necessary. The globalizing economy places more importance on education, training and basic competencies and skills as key factors in investment, trade and competition for jobs and markets. For its level of development, Latin America is seriously deficient in its human capital. This, together with the fact that the region has one of the highest levels of income inequality in the world, makes it extremely difficult to improve education because education is not just what is learned in school but consists just as much of the educational capital built up at home and the social capital accumulated in daily life.

The disparity between the quality of private and public education is exemplified by the tests applied to eighth grade students in Chile in 2000. Although 60\% of all students attend municipal schools, only 5\% of these children figured in the highest achievement group, whereas $85 \%$ of the highest achievers came from private schools in well-off neighbourhoods, where the children already arrive at school with a "learning culture". (The remaining 10\% came from State-aided private schools).

Equally worrying is Chile's performance in international tests that measure adult competencies. These measurements have shown very dramatically that functional illiteracy among adults is a much larger problem than was previously assumed, precisely when 
the labor market is demanding increasing high levels of skills. Likewise, the performance of 15-year-olds in 2000 in Mexico and Brazil shows that the pattern of insufficient competencies in the adult population persists even in the case of the latest cohorts coming out of educational systems that have undergone significant reforms and received heavy financial investments. It is likely that other countries in the region have a similar or even worse performance. Until more countries measure and monitor their education systems and their student and adult competencies we can only point to the experiences of this limited set of countries which have participated in international education measurement programmes. We really need to have this important information for each and every country in the region.

Of the factors studied in the analysis of wages, educational attainment is one of the most important determinants of earnings in most countries, even when variations in the other factors are taken into account. This supports the proposal that the highest priority should be to retain students until they graduate from upper secondary school, since high school graduation is not only a benchmark of educational achievement in itself but also opens the way to tertiary education. Analysis of the premiums for education in terms of earnings demonstrate this very clearly for the five countries studied. We have also seen that, in the absence of other "quality factors", employers use certificationbased methods to choose who they will hire. Educational credentials such as high school graduation certificates, college degrees, etc., are therefore extremely important: even more so than experience alone.

\section{A policy agenda for confronting globalization}

The policy agenda should be based on the underlying principle of seeking greater equality, because it is the very severe inequity in the region - particularly in education and job opportunities - that makes change so difficult and holds countries back in global competition. The following proposals will enable the region to confront globalization, allow the countries to grow in a sustainable manner, and equip individuals to maximize their potentials.

- Completion of upper secondary education by all students should be established as a priority goal. Universal access should be provided to formal secondary education that incorporates technical training, with opportunities for dual learning, part work-based, part school-based, with priority being given to the poorest students.

- To the extent that resources permit, improved access to tertiary education should be afforded to all segments of the population, through generous scholarships, student loans and work-study programmes, so that talented poor children can get to the best universities.

_ "General higher education" should be introduced as a formal higher education option to complement the specific so-called "professional" options of law, economics and other courses leading to professional careers in these areas. General higher education fits in well with the market for managerial and service-sector occupations, which account for the majority of the labor force in Latin America and the Caribbean.

- The financing and efficiency of education systems should be improved and alternatives to public financing should be sought in the private sector.

- The business and industrial sectors should be brought in as active, engaged participants. Governments and the private sector should work together to unite the business and education sectors in an effort to implement effective school-based and firm-based training schemes. This involves identifying the thorny questions that set up barriers, and working to break them down.

- Macro reforms almost always take the front seat. It is at the micro level, however, that much more work is needed to deepen the reforms and provide a level playing field so that countries and their citizens can confront globalization. This is the region's challenge for the future.

(Original: English) 


\section{Bibliography}

Akerlof, G.A. (1970): The market for lemons: Quantity, uncertainty and the market mechanism, The Quarterly Journal of Economics, vol. 84, No. 3, Cambridge, Massachusetts, Harvard University Press.

Amjad, R., P. Reboani and G. Sziraczki (2001): Key issues in education and training statistics, in P. Garonna and others (eds.), Achieving Transparency in Skills Markets, Milan, Italy, Franco Angeli.

Bravo, D. and D. Contreras (2001): Competencias básicas de la población adulta, Santiago, Chile, Ministry of Economic Affairs, Development and Reconstruction / University of Chile, Department of Economics / Production Development Corporation (CORFO).

Bravo, D. and others (2001): Formación dual: un desafio para Chile, Santiago, Chile, University of Chile.

Brazilian Geographical and Statistical Institute (IBGE) (1993): Pesquisa nacional por amostra de domicilios, Rio de Janeiro, Brazil.

(1999): Pesquisa nacional por amostra de domicilios, Rio de Janeiro, Brazil.

Carlson, B. A. (1998): Measuring labour market outcomes of education, Household Surveys: Redesign of the Current Household Survey of Argentina. First meeting on Public Statistics of the Inter-American Statistical Institute (IASI), Buenos Aires, June.

(2001): Education and the labour market in Latin America: why measurement is important and what it tells us about policies, reforms and performance, "Desarrollo productivo" series, No. 114, Santiago, Chile, Economic Commission for Latin America and the Caribbean (ECLAC).

(2002): Job losses, multinationals and globalization: the anatomy of disempowerment, "Desarrollo Productivo" series, No. 132, Santiago, Chile, Economic Commission for Latin America and the Caribbean (ECLAC).

Carlson, B. A. (ed.) (1999): Social dimensions of economic development and productivity: inequality and social performance, "Desarrollo productivo" series, No. 56, Santiago, Chile, ECLAC.

Castro, C. and C. Levy (2000): Myth, Reality and Reform: Higher Education Policy in Latin America, Washington, D.C., InterAmerican Development Bank (IDB)

Centre for Educational Research and Innovation (CERI) (1998): Human Capital Investment: An International Comparison, Paris, Organisation for Economic Co-operation and Development (OECD).

(2001a): Education Policy Analysis, 2001. Education and Skills, Paris, OECD.

(2001b): The Well-being of Nations: The Role of Human and Social Capital, Paris, OECD.

Department of Statistics, Surveys and Censuses (DGEEC) (1994): Mano de obra. Encuesta integrada de hogares, Asunción, Paraguay.

(1999): Mano de obra. Encuesta integrada de hogares 97/98, Asunción, Paraguay.

ECLAC (1992a): Social Equity and Changing Production Patterns: An Integrated Approach, LC/G.1701/Rev.1-P, Santiago, Chile.

(1992b): Education and Knowledge: Basic Pillars of Changing Production Patterns with Social Equity, LC/G.1702/ Rev.2-P, Santiago, Chile.
(1998): Social Panorama of Latin America, 1997, LC/G.1892-P, Santiago, Chile.

Katz, J. (2000): Reformas estructurales, productividad y conducta tecnológica en América Latina, Santiago, Chile, Fondo de Cultural Económica/ECLAC.

Ministry of Planning and Cooperation (MIDEPLAN) (1998): Encuesta de Caracterización Socioeconómica Nacional (CASEN) 1996, Santiago, Chile.

(2000): Encuesta de Caracterización Socioeconómica Nacional (CASEN), Santiago, Chile.

National Institute of Statistics (INE) (1994): Encuesta contínua de hogares, Montevideo.

(1999): Encuesta contínua de hogares, Montevideo.

National Institute of Statistics and Censuses (INDEC) (1994): Encuesta permanente de hogares, Buenos Aires.

(1999): Encuesta permanente de hogares, Buenos Aires.

Ocampo, J. A. (2001): More Jobs, Better Jobs, Social Panorama of Latin America 2000-2001, Santiago, Chile, ECLAC.

OECD (1996): Measuring what People Know: Human Capital Accounting for the Knowledge Economy, Paris.

(1997): Economic Surveys: Mexico 1996-1997, Paris.

(2000a): Literacy in the Information Age, Paris.

(2000b): Education at a Glance. OECD Indicators 2000, Paris.

(2000c): Investing in Education: Analysis of the WEI Indicators, Paris.

(2001a): Knowledge and Skills for Life: First Results from PISA 2000, Paris.

(2001b): Education at a Glance. OECD Indicators 2001, Paris.

(2001c): Economic Surveys: Brazil 2001, Paris.

Reimers, F. (ed.) (2000): What can we learn from studying educational opportunity in the Americas, Unequal Schools, Unequal Chances: The Challenges to Equal Opportunity in the Americas, Cambridge, Massachusetts, Harvard University Press.

Reinhardt, N. and W. Peres (2000): Latin America's new economic model: Micro responses and economic restructuring, World Development, vol. 28, No. 9, Oxford, U.K., Pergamon Press, Ltd.

Salmi, J. (2001): Tertiary education in the 21st century: Changes and opportunities, Journal of the Programme on Institutional Management in Higher Education: Higher Education Management, vol. 13, No. 2, Paris, OECD.

Schumpeter, J. (1950): Capitalism, Socialism and Democracy, London, George Allen \& Unwin Ltd.

UNESCO (United Nations Educational, Scientific and Cultural Organization) (1997): International Standard Classification of Education: ISCED-97, Paris.

(2000a): World Education Report 2000, Paris. (2000b): UNESCO Statistical Yearbook 1999, Paris.

Weller, J. (2001): Economic Reforms, Growth and Employment: Labour Markets in Latin America and the Caribbean, Santiago, Chile, ECLAC.

World Bank (1999): World Development Report 1998/99. Knowledge for Development, Washington, D.C.

(2000): Poor People in a Rich Country. A Poverty Report for Argentina, Washington, D.C. 